\title{
Aspirationalism: The Search for Respect in an Unequal Society
}

\section{Michelle Gabriel}

In the run-up to the 2001 federal election, Australia's national political radar settled on a new, influential constituency: the upwardly mobile lower-middle class, the up and coming, or, most simply, the aspirationals. As with all sizeable demographic groups, the aspirationals were wooed by Australia's two major political parties, both of which could legitimately claim them as a logical adjunct to their core constituencies: while the aspirationals are the children of Labor's industrial workers, they are now typically putting in long hours at the office in order to service a mortgage in a marginal Liberal seat. Of course, such a group could not please everyone; following the rush of enthusiasm for the aspirational vote, several Australian political commentators denounced the phenomenon as repugnant. ${ }^{1}$ Their gripe was predictable, but nevertheless an incisive one. They railed against the ingratitude of the aspirationals, who were said to have betrayed their working-class roots, and against the aspirational's vulgar desire for personal advancement, which they viewed as an affront to their dream of an egalitarian Australia. Although national debate has moved well beyond this relatively minor outburst, the disparagement of the aspirationals is indicative of a deeper tension in Australian political life over whether or not egalitarianism can endure into the twenty-first century, and how such a project might best be achieved. While some seek to redefine the scope and nature of egalitarianism and to refashion the Australian egalitarian project in the light of changed national circumstances, others view such reinvention as a renouncement of the core principles of the Australian egalitarian project and instead have called for the reinvigoration of a corporatist model of Australian governance. ${ }^{2}$

This article contributes to the national conversation about egalitarianism and Australian governance by examining in greater detail some of the issues surrounding the fissure between defenders of the egalitarian project and aspirational workers. Rather than expressing further moral outrage at the aspirationals, I present a critical review of the egalitarian project and a more generous reading of the aspirationals, or rather upwardly mobile Australian workers. As part of my review, I specify the key features of egalitarianism as evoked by those who spoke out against the aspirationals and identify some of the tensions and oversights within this principled stance on egalitarianism. These include an incomplete understanding of the origins of contemporary inequalities, the contradictory treatment of fraternity and equality by egalitarians, and an uneasiness about the practical management of inequality. Drawing on interviews with young people about their experiences of social mobility, I isolate the pressures on young people to 'get ahead' and the problems that arise when people try to distinguish themselves from one another. I conclude by noting that the aspirationals are not the antithesis of egalitarianism but, rather, the aspirationals are particularly well placed to contribute to debate over the reinvigoration of Australian egalitarianism. 
Write/up

\section{Egalitarian Australia: Defending a noble tradition}

In both the celebration and the reappraisal of Australian national identity, politicians, historians and cultural commentators routinely evoke Australia's egalitarian heritage. Such mythologising draws heavily on the early idealism of European settlers and British convicts who sought an alternative to the repressive class system of their homeland, and the mateship and comradeship forged among pioneers and bushmen who banded together in order to survive in a foreign and harsh environment. More substantively, Australia's egalitarian heritage commemorates the progressive achievements of Australian policy-makers. These include the early extension of voting rights to women, ${ }^{3}$ the establishment of the national Conciliation and Arbitration Court at federation, the turn towards economic planning, and the introduction of comprehensive social insurance measures during the period of post-second world war national reconstruction. From the 1970s, the expansion of post-compulsory education, the introduction of anti-discrimination and anti-vilification legislation, and recognition of the civil rights and native title claims of Indigenous Australians enhanced the egalitarian social agenda. Australia's egalitarian credentials also stem from the country's remarkable prosperity as both a colony and a nation, particularly throughout the post-second world war period; a prosperity that underpinned decent wage levels and working conditions for Australians workers, relatively high standards of living, and relatively high levels of inter-generational, predominantly upward, mobility. ${ }^{4}$

Of course, Australia's history as an egalitarian nation is highly contestable, and the notion of egalitarianism is itself subject to considerable reinvention. While historians have pointed to substantial blind spots within the egalitarian narrative, particularly in regards to the fair and equal treatment of Indigenous Australians, women, and non-Anglo immigrants, ${ }^{5}$ social scientists have noted the persistence of class inequality and poverty in Australia throughout the twentieth century. ${ }^{6}$ Despite these contentions over Australia's egalitarian credentials, the fluidity and adaptability of the Australian version of egalitarianism has enabled this sentiment to survive in the face of political change and historical revision. ${ }^{7}$ Among the many variants of egalitarianism deployed in Australian public life, the main contenders include: collective egalitarianism, working together for the collective good; antiestablishment, a distrustfulness of those who claim authority; classlessness, the absence of class consciousness; sameness, the common consumption of services and culture; and equal opportunity, access to the same opportunities to participate in public life. Stock phrases such as 'mateship' and 'fair go' are also used to denote a broad church of egalitarianisms, from the equal treatment of all citizens to the capacity to provide fair competition for all.

Recognising the various types of egalitarianism is essential in making sense of the fissure between advocates of the aspirationals and those who spoke out against the aspirational phenomenon in the period surrounding the 2001 federal election campaign. Although those who spoke out against the aspirationals did not speak with a uniform voice, they agreed on three issues. First, the aspirationals are not a real social group, but rather they are a marketing 'con-job'. ${ }^{8}$ Both Thomas Keneally and Tom Morton felt that aspirationalism was little more than an attempt to project 'me first' values on to the lower middle classes. ${ }^{9}$ They asserted and 
hoped that the aspirationals were an invention of the free-market prophets. Second, despite questioning the authenticity of the group, these critics were able to clearly depict the main traits of the aspirationals, as derived from political analysts and marketing experts. Accordingly, the aspirationals were said to be: materialistic, in that they seek financial gain above all else; ${ }^{10}$ apolitical, in that they swing towards the party that offers them the biggest tax break; ${ }^{11}$ and selfobsessed, in that they seek to improve themselves and their circumstances at the expense of others. ${ }^{12}$ Thirdly, aspirationalism and egalitarianism were pronounced political enemies. In Thomas Keneally's words, 'Aspirational is an ugly adjective, which countenances an idea uglier still. It countenances the end of egalitarianism'.${ }^{13}$ As enemies of egalitarianism, the aspirationals were accused of being more interested in securing private benefits than protecting the public good, and of being 'fanatically anti-union'. ${ }^{14}$ In articulating their concern over the decline of Australia's egalitarian project, these critics did not appeal to a universal but, rather, a highly specific form of egalitarianism. They evoked a traditional leftist version of egalitarianism grounded in the collectivist struggles of Australian workers, and focused on the equal distribution of income and access to social services.

While the resuscitation of this noble tradition is appealing - particularly given the increase in income inequality over the past two decades ${ }^{15}$ - such a resuscitation is certainly not without its problems, nor would it lead, as some would hope, to the eventual demise of the aspirationals and their 'ugly' materialistic tendencies. Indeed, the aspirationals are not the antipathy of egalitarianism but the very product of the egalitarian measures that these commentators hope to restore. The progressive educational reforms of the Whitlam government gave thousands of working-class students a leg-up Australia's socio-economic hierarchy; as such, it is rather churlish of the 'egalitarian parents' to accuse their 'aspirational children' of being 'working-class Tories'. ${ }^{16}$

\section{Egalitarian revisions: Addressing the problem of class mobility}

The version of egalitarianism evoked by critics of the aspirational phenomenon draws on a number of arguments and assumptions about inequality that have previously been rehearsed in Australian political life, particularly in regards to the expansion of educational opportunities in the post-second world war period. Throughout this period education was viewed as the key to addressing social inequality, and was supported by successive governments from the 1940s onwards, most notably during Whitlam's term in office when the level of federal funding for education increased substantially, but also under conservative prime ministers such as Sir Robert Menzies and Malcolm Fraser. Still, it was the funding windfall under Whitlam's stewardship that enabled educationists to comprehensively revise their strategies for overcoming barriers to participation in education. During this period the 'social equality' goal-posts shifted rapidly. Once the education system had begun to offer equal access for all, it became apparent that it was failing to attend to the effects of class-based disadvantage on educational access. Once the education system had begun to facilitate greater access to disadvantaged students, it became apparent that it was not attending to 
the effects of class-based disadvantage on educational outcomes. Eventually, once the education system had begun to show signs that it was facilitating meritorious outcomes, it became apparent that it was not attending to the market-induced inequities of modern society. By the late 1970s, more radical voices had raised the critical stakes in their critique of the limits of social democratic interventions and in their comprehensive denouncement of the egalitarian enterprise. They argued that the application of egalitarian measures in the field of education was sociologically naïve, in that the education system was itself viewed as an instrument for the reproduction of capitalist society, and they ambitiously called for revolutionary change. ${ }^{17}$

Although such a brief review cannot do justice to the complexity of the arguments put forward by educationists in the post-war period, it does signal some of the tensions that have arisen under the umbrella of advancing social equality; tensions that are either forgotten or obscured in recent calls to resuscitate old egalitarianism. Certainly, the arguments put forward by radical educationists in the late 1970s are important in highlighting the gap between egalitarian measures and egalitarian outcomes, and the problems posed by the implementation of egalitarian measures in an unequal society. This fundamental contradiction between egalitarian social policy and an un-egalitarian society is a theme that has recently resurfaced in contemporary debates over the problem of inequality, particularly in the work of cultural historian and sociologist Richard Sennett. While Sennett concurs with the problems raised by radical educationists, he specifies a lessrevolutionary path for fostering a more respectful ethos and a more egalitarian society. ${ }^{18}$ In contrast to previous efforts aimed at attacking social inequality, Sennett takes issue with three of the assumptions implicit in more radical variants of egalitarianism: that the fundamental source of inequality is capitalism, that the basis of inequality is differences in material wealth, and that the struggle for equality is one between bosses and workers. Instead, he reconsiders the origins of contemporary inequality. In doing so, he recognises the tensions that arise between 'fraternity' and 'equality' with the realisation of egalitarian measures, and he shifts the egalitarian focus from the question of 'how to eradicate inequality' to the question of 'how to manage inequality' in everyday life.

In public debate, the origins of contemporary inequality are rarely contested; instead there is a commonsense understanding that such inequalities are a product of historical prejudices and a consequence of free-market economics. In contrast, Richard Sennett argues that such a view is slightly misleading and rather dangerous in the sense that such assumptions overplay the power of egalitarian policies to remove these annoying, old-fashioned prejudices, and underestimate the injurious effects of contemporary sources of inequality. In his early study of working-class men in Chicago in the 1960s, Sennett and his colleague Jonathon Cobb traced the origins of contemporary inequality beyond the gross injustices and humiliations experienced by factory workers in industrial England in the nineteenth century to the liberal banter of the French philosophes of the eighteenth century. ${ }^{19}$ In this period of scientific and cultural revolution, Enlightenment thinkers such as the French philosophes critiqued what they saw as the major obstacles to human endeavour and progress: religious doctrine, undemocratic monarchical rule, and a society in which reward is granted based on inheritance 
rather than talent. Of course, the Enlightenment was not merely an intellectual movement but was also a program for change. With the creation of the French Republic in 1789 and the establishment of European colonies in the new world, new leaders and administrators were able to translate, at least partially, the ideas of the Enlightenment movement into practice. For Sennett and Cobb, here marks the beginning of a gradual but fundamental change in the distribution of reward throughout society. Once seen as a birthright and sanctioned by God, reward from the late eighteenth century onward is granted on the basis of talent and performance. In short, the lynchpin of contemporary inequality for Sennett and Cobb is the 'opening up of careers to talent'. ${ }^{20}$

Although Sennett has much in common with more radical stances on egalitarianism in that he recognises the enduring problem of inequality, he rejects the socialist egalitarian vision of society founded on working-class solidarity. Reflecting on his own radical heritage, Sennett recognises not only the implausibility of a new social order based on equality but also the fundamental contradiction between a politics based on class-consciousness and a politics based on equality. ${ }^{21}$ Sennett notes that one of the dilemmas faced by defenders of the socialist egalitarian project is that the project relies on the expression of strong fraternal bonds among comrades, with a corresponding hatred of the bourgeois enemy. Sennett's work also draws attention to antagonisms between fraternity and equality that have arisen as a consequence of well-intentioned egalitarian campaigns to remove the effects of class or socio-economic status on educational outcomes. One key tension, glossed over by critics of the aspirationals, is the fundamental dilemma faced by the children of the working poor: do I follow the path to self-advancement and risk distinguishing myself from my peers, or do I keep my head down and stick by those around me? This is what Sennett and Cobb refer to as the 'divide between achievement and fraternity'; 22 that is, the conflict between a person's desire to assert their self-worth and their desire to belong. Although this divide is exacerbated through the expansion of egalitarian measures, it is children of the working poor who have to resolve this dilemma by being both 'high achievers' and 'good mates'. While the aspirationals have succeeded at the former, they are found to be deficient in regards to the latter.

In rejecting the revolutionary ambitions of radical egalitarians, Sennett instead turns the spotlight on the practicalities of how people manage inequality in a modern and unequal society - an issue that is either offensive or redundant to those working towards the eradication of such inequality. Returning to the twentieth century, Sennett and Cobb specify some of the enduring problems associated with the opening up of careers to talent, in particular, the problems faced by people living under these new, modern arrangements. They argue that for people who live in this society, the key problem is not class per se but the fact that class boundaries are permeable — with the caveat that they are only permeable for some, namely those who possess distinctive personal abilities. In the absence of preordained roles, a new division based on merit and talent is installed. Under this 'more just' and 'less arbitrary' system, respect is reserved for those who succeed on their own merit, and, in turn, respect is denied to those who do not. Here Sennett delivers his central thesis, first articulated in the Chicago study and then elaborated in his more recent autobiographical work: 
In society, attacking the evils of inequality cannot alone generate mutual respect. In society, and particularly in the welfare state, the nub of the problem we face is how the strong can practice respect toward those destined to remain weak. ${ }^{23}$

Sennett's thesis of 'respect' is informed by his own life-experiences and the personal accounts of Chicago workers that he collected early on in his research career. These accounts provide particular insights into the general problem of equality and education, and the specific ways in which respect is denied to the working poor and the uneducated in everyday interactions. In contrast to the commonsense view of the universal 'goodness' of education - a view that has prevailed in post war Australia - the Chicago workers see education in wholly different terms. For them, 'Certified Knowledge' is a tool that has been used against them, and their lack of education is a source of shame in their public lives. ${ }^{24}$ Ironically, what is a source of freedom for those who succeed within the educational system is for these working-class men a source of personal indignity. ${ }^{25}$ While the Chicago workers feel that they cannot change their situation, what they can do is work hard to ensure that their children have the opportunity to get an education and enjoy the material, cultural and personal rewards that are granted to the person who possesses 'Certified Knowledge' — the hard evidence of talent and ability in modern society.

Richard Sennett's analysis sheds light on the conditions under which the aspirational Australian has emerged and the dilemmas that confront the upwardly mobile. While the prevalence of upward mobility in Australia throughout the postwar period is partially attributed to occupational and industrial restructuring, Sennett's work is a reminder that the drive to succeed among children of the working poor is symptomatic of a society in which class is relatively permeable and respect is afforded to those who demonstrate distinctive abilities, a policy environment in which disadvantaged children are encouraged to finish school and out-compete their peers, and a home environment in which children are expected to earn the respect denied to their parents. While it is true that children of the working poor must work hard to please both policy-makers and their parents, they have also learned that working too hard and distinguishing themselves too much can threaten their relationship with their peers; they aspire, but not too much. As Mungo MacCallum so cogently put it:

The aspirational voter is not a joiner unless a free ride is involved. But nor is it in any sense a rugged individual; to stand out in any way is only to invite suspicion from other aspirational voters. It is something of a contradiction in terms: a herd animal without any real interest in the welfare of the herd as a whole. ${ }^{26}$

While MacCallum and others did pick up on some of the key tensions that the aspirationals face, their comments revealed a nagging contradiction between their abhorrence at the move towards a more competitive, selfish and individualistic Australian society, and their own tendency to position the aspirationals as individual, free agents, rather than 'social selves'. This severing occurred at two levels: not only did such commentators fail to recognise that the aspirationals might, to some degree, be a product of the society they live in, they did not appreciate that such 'working-class traitors' were caught in a complex web of familial and fraternal relationships that cross-cut class boundaries. While the 
aspirationals, or rather the upwardly mobile, are far from perfect, they are not apolitical and ahistorical monsters, as many would have it. Instead, the aspirationals can tell us much about the problems that arise in a modern, unequal society when people, in their search for respect, try to distinguish themselves from one another.

\section{Aspirational lives: The ambitions and loyalties of ordinary Australians}

Since careers were first opened up to talent and class became relatively permeable, many people have depicted the experience of upward and downward social mobility. Following this tradition, I interviewed the children of workers from economically depressed industrial towns on the northwest coast of Tasmania about their experiences of leaving their home town, which for most marked the beginning of their upwardly mobile careers. While not all of these young people fit comfortably in the aspirational box, several recounted their experiences of being socially mobile and tragically aspirational. ${ }^{27}$ One young aspirational, Kate, was particularly reflective about her personal ambitions and her aspirational life:

I decided that I didn't want to be, you know, a housewife, which I don't look down on at all, but at the time, I think I wanted to be someone who other people could, you know, admire, or not look down on. I knew I wanted to go to university because I sort of thought if I went to university I would always be able to win arguments because I'd become so much smarter. So I suppose going to university was a way I could achieve that. ${ }^{28}$

She spoke frankly about three defining points in her upwardly mobile life: realising that her rather ordinary lifestyle and working-class culture was not coveted by others; trying to learn the complex manners of Australia's loosely defined cosmopolitan middle class; and finally reconciling the cultural and material gaps between herself and the family and friends she had left behind.

Leaving the family home is a difficult but exciting time. While some of the young people I interviewed from the coast reflected on their working holiday adventures beyond Bass Strait, for those hardworking types who followed their teacher's advice and immediately enrolled into university, the transition was somewhat more difficult. While they all received considerable support from their parents, they each found the adjustment tough as they faced a multitude of challenges: leaving home, moving to a different state or city, saying goodbye to an old circle of friends, and adjusting to the demands of university life. Reflecting on these early days at university, all commented on the physical and cultural differences between their coastal home and the city. For some it was adjusting to work regimes that they found the most difficult to handle, for others there were other, more embarrassing, issues to cope with; namely, the absolute confidence and assuredness of the children from privileged middle-class backgrounds. As Kate observed:

I was really homesick, really miserable and my parents were pretty miserable too. It was really hard for me I think because I was living in one of the university colleges, which is never good, but I didn't like the people in the college. They were not really much like me. And they were all - I suppose they felt that the people from [name omitted] were not as good as they were and so I used to get really angry about it ... 
Write/up

They just felt that they were naturally better than other people and there was, I suppose, a feeling of non-identification with anyone who wasn't working in a professional job or hadn't come from a background whose parents were working in a professional job.

Whether it was a question of geography or the school that you went to, one of the lessons that these young people soon discovered was that there are right and wrong hometowns, high schools and attitudes. The shame of being wrong on all these counts was felt not just in relation to themselves, but also in relation to their families. As Kate notes:

I was half-torn between wanting to say this is what they do for a living, you know - shut up - and at the same time wanting to hide it for my parents' sake. Because I thought my parents would be embarrassed if they knew that I was telling these people what they did. Because my parents know better than anyone that they're looked down on by middle-class people.

Through their encounters at university, these new students gradually began to understand that there was something not quite right about them and that they not only needed to improve their mind but they also needed to sharpen up their manners, their speech, their tastes and their appearances. Kate talked about a transitional period of 'self-gentrification' in which her and her sister embarked on a dramatic personal makeover.

My sister went through a process of gentrification. She used to do all the things my parents did - like drinking instant coffee, you know, that sort of thing — and then when she moved to [name omitted] she started dressing differently, and started speaking differently, and she'd try and keep up with her friends who were all fairly well-educated. We were both going through this process, but she went a little further than I did.

While these times were viewed as fun, Kate also expressed the sentiment that you can go 'too far', to the point that it would be insulting to her parents.

I think she's a bit more embarrassed about coming from [name omitted] than I am, and she's a bit more embarrassed about little slip-ups that she makes as a working -class person. It was scary actually. We were buying my mum a Christmas present and she said 'Oh, what about a plunger?' and I said 'Mum doesn't drink plunger coffee', and she said 'Well, it's about time she did', and I went 'Oh dear'.

The most difficult problem for all the young people interviewed who left the coast, particularly for the more aspirational among them, is reconciling the differences between their 'new' selves and their 'old' lives, and the cultural and material gaps between themselves and their families. Kate discusses the discomfort that arises on her return home:

It was a period of adjustment because I had to go back to my family and try not to be one of these people that I was taught to dislike when I was growing up ... So when I went home it was difficult. I had to make sure that I wasn't one of those people [a snob] and so it was a very, jolted-type of conversation, and I had to make sure I didn't say dinner instead of tea for the evening meal, and things like that, or my parents would say, 'Dinner? Where did you pick that up from?' ... I had to make sure that my parents didn't think that I was looking down on them, and that was the major thing for me. And I knew that I wasn't, but they were very sensitive about it, so I had to be really careful. Yeah, that was the thing that was hard. 
Still, Kate believes that she is fortunate in that she has been able to establish a new relationship with her parents; one that accommodates, rather than ignores, her experiences at university and on the mainland.

Before I went to university my parents - I mean my father's always been very, very political, but never spoken about it - I suppose our relationship was based on the type of things that you do when you're young, like going on picnics, but since I've been to university and I've studied politics, now when I come home we talk about politics and work and I think that's the way we connect.

In contrast, she is worried that her sister might not be able to negotiate this gap:

She gets on well with my parents, but it's always, a bit, kind of a feeling, a distance between them that I think she likes to keep there, because she's finished with working class now. She's middle class and that's the end of the story.

The personal dilemmas that confront Kate - the drive to achieve, to be more middle class, to be a good child, to be a watchful sister, to be true to her workingclass roots, to be true to herself - these are what Sennett and Cobb call the 'hidden injuries of class'.

\section{Egalitarian traditions, aspirational lives and Australian governance}

While the media-friendly aspirationals were courted by both major parties throughout the 2001 federal election campaign, once the ballot box closed the aspirational phenomenon was immediately declared a 'staid cliché'. ${ }^{29}$ Still, during their brief time in the public eye, the aspirationals managed to attract the ire of numerous Australian social commentators and opinion writers, who accused the aspirationals of being materialistic, politically disloyal, and anti-union. Moreover, these commentators drew a clear distinction between their own principled stance on egalitarianism and the corrosive effects of the aspirationals on the egalitarian project. Such oppositional positioning is, as I have argued, terribly misleading in that it exonerates the egalitarians from any responsibility for the creation, or at least the proliferation, of aspirationalism, and it glosses over the tensions that arise under the umbrella of 'social equality'. It also assumes that there is one path back to egalitarianism. In doing so, it devalues recent attempts to reinvent Australia's egalitarian project. While it is easy to dismiss the strange alliances that have circulated in recent debates, such as 'aspirational equality' and 'fair competition', as repugnant oxymorons, such clumsy, hybrid associations represent attempts to address the contradictory effects of egalitarian interventions in an unequal society; effects that were not anticipated by the egalitarians of the past.

Aspirational Australians live in a tough, competitive and unfair society. However, this is not just a product of the recent stink of neo-liberalism but, rather, as Sennett reminds us, a product of the progressive, liberal thinking that prevailed in the eighteenth century. While governments, if they so choose, can intervene and make a difference in regards to the distribution of material wealth and access to social services, they cannot removed the invidious problem of envy and comparison. For the aspirationals, the problems they face in living in a society in which the lines of class are permeable, but permeable only for some, are their own. They will have to resolve the persistent dilemma: why are my successes a victory 


\section{Write/up}

for my class, for 'people like me', but my failures a reflection of my personal limitations? They will have to make the call when it comes to judging the degree to which they choose to stand out and develop themselves, and the degree to which they follow their peers in order to belong. In contemporary Australia, the opportunities for greater mobility and personal makeover are still expanding, and yet - as the aspirationals have learned — such upward moves are always doubleedged. While personal development can increase a person's chance of attracting material wealth and societal respect, the persistent drive to self-improve can also feed personal anxieties and undermine relationships with others. Given that the aspirationals have a 'head start' on tackling some of the difficult dilemmas that arise in a permeable, but unequal society, and given that they have experienced directly the tensions that arise when governments try to facilitate more egalitarian outcomes, the aspirationals - despite what some may think - have a privileged vantage point in the current debate over the reinvigoration of Australian egalitarianism. They should not be discounted as self-obsessed 'shopping-mall men' ${ }^{30}$ 


\section{Aspirationalism: The Search for Respect in an Unequal Society} Michelle Gabriel

1 David Burchell cites several such commentators - Thomas Keneally, Tom Morton, Kenneth Davidson and Mungo MacCallum in his online discussion paper: 'Sea-Change in the Suburbs?', 7 May 2002, http://www.apo.org.au/webboard/items/00006.shtml.

2 Compare Mark Latham, From the Suburbs: Building a Nation From Our Neighbourhoods, Pluto Press, Sydney, 2003, with Fred Argy, Where to From Here? Australian Egalitarianism Under Threat, Allen and Unwin, Sydney, 2003.

3 However, Indigenous women did not achieve universal suffrage until 1967.

4 Mark Western, 'Class in Australia in the 1980s and 1990s' in J M Najman and J S Western (eds) A Sociology of Australian Society, 3rd ed, Macmillan, South Yarra, 2000, p 79.

5 Richard Nile (ed), The Australian Legend and Its Discontents, University of Queensland Press in association with the API Network, St Lucia, 2000.

6 Janine Baxter, Michael Emmison, John Western and Mark Western (eds), Class Analysis and Contemporary Australia, Macmillan, South Melbourne, 1991.

7 Robert Hogg, 'Myths and markets: Australian culture and economic doctrine', Journal of Australian Studies, no.72, 2002, p 241.

8 A sentiment expressed by several commentators: Tom Morton, 'Shopping-mall man and woman', Age, 7 July 2001, p 4, Thomas Keneally quoted in Tony Stephens article 'Keneally laments 'ugly' way of being', Age, 7 December 2001, p 3, and Hugh MacKay, 'Hands up, all you aspirational weirdos', Age, 8 December 2001, p 7.

9 Morton, op. cit., and Stephens, op. cit.

10 Shaun Carney, 'A landslide that never was', Age, 9 March 2002, p 7.

11 Antony Green, 'Outer suburbs will decide who rules', Age, 13 January 2001, p 5.

12 Shaun Carney, 'Howard's Australia: seal the borders and celebrate the past, Age, 22 December 2001, p 1 .

13 Stephens, op. cit.

14 Mungo MacCallum, 'No altruism in the new "aspirational voter"', Northern Rivers Echo, 
Notes to pp 149-159

15 January 2001. A similar sentiment was expressed by Kenneth Davidson, 'How the ALP lost its soul', Age, 29 November 2001, p 17.

15 Anne Harding and Harry Greenwell, Trends in Income and expenditure inequality in the 1980s and 1990s - A Re-examination and Further Results, Discussion paper no. 57, NATSEM, Canberra, June 2002.

16 Terry Lane, 'Unity: A modern idea gains new currency', Age, 30 December 2001, p 12.

17 These arguments, which had a brief airing among educationists in Australia, are derived from the work of Samuel Bowles and Herbert Gintis, Schooling in Capitalist America: Educational Reform and the Contradictions of Economic Life, Basic Books, New York, 1976.

18 Richard Sennett, Respect: the Formation of Character in an Age of Inequality, Allen Lane, Penguin Press, London, 2003.

19 Richard Sennett and Jonathon Cobb, The Hidden Injuries of Class, Cambridge University Press, Cambridge, 1977.

20 ibid., pp 245-62, 250.

21 Sennett, op. cit., p 255.

22 Sennett and Cobb, op. cit., p 101.

23 Sennett, op. cit., p 263.

24 Although Sennett and Cobb do not explicitly define the term 'Certified Knowledge', they use this term to denote those educational achievements that are institutionally recognised such as high school graduation or the completion of a university degree, as opposed to the accumulation of folk knowledge or domestic skills. See Sennett and Cobb, op. cit., pp 24-31.

25 Sennett and Cobb, op. cit., p 30.

26 MacCallum, op. cit.

27 This article comes out of a $\mathrm{PhD}$ research program in which I interviewed eighteen young people from the Coast, twelve of whom might be considered upwardly mobile, in that they were the first in their family to attend university or they were working in comfortable jobs in the service sector on the mainland or overseas.

28 Interview with Kate, 10 January 2002.

29 Gerard Henderson, 'Aspirations come and go — so do clichés', Age, 11 December 2001, p 13.

30 Morton, op. cit. 